\section{Establishment of the Indigenous Microbial Flora of the Intestines in the Course of the Evolution of Vertebrates}

It is highly probable that many parasites have evolved contemporaneously to their hosts, parasitism being a very long-standing phenomenon and an early biological trait of vertebrates (CAMERON ${ }^{1}$ ). While investigations of comparative parasitology have been carried out, e.g. on sclerostomata, no serious attempt has been made to evaluate the association of the intestinal microbial flora with the evolutionary development of vertebrates: it is well known that the indigenous flora inhabits the gut of mammals and also of birds; but information appears scanty or misleading in the case of cold-blooded animals.

From the alimentary tract of the common gartersnake (Tamnophis sirtalis sirtalis), MERGENHAGEN ${ }^{2}$ isolated bacteria belonging to eight genera and stated that 'there seems to be little if any difference in the bacterial flora of the alimentary canal of poikilothermic and warm-blooded animals'. His conclusion, being gratuitously extended to poikilothermic animals in general, seems wrong, since a true microbial flora appears to be absent in the intestine of fish, which, after brief periods of fasting, tends to become sterile. 'There are no common bacterial commensals in the intestine of fish, but the presence of a bacterial flora depends solely upon the recent intake of food and water' (MARGoLIS ${ }^{3}$ ).

Similar conclusions are shared by PotTer and BaKer ${ }^{4}$, GuÉlin $^{5}$ and HugGins and RASI, only Liston ${ }^{7}$ suggesting a hypothetical analogy between the coliform population of mammalian gut and some intestinal groups of genus Vibrio, isolated from specimens of Pleuronectes microcephalus and Raja sp. But this suggestion awaits confirmation.

Our investigations were directed towards the study of the missing ring of the chain, i.c. amphibia, in particular those living chiefly in an aquatic environment. Comparative experiments were performed on newts (Tritumus cristatus carnifex), frogs (Rana esculenta) and, for reference, a teleost, the goldfish (Carassius auratus). Twelve adult specimens of each species were acclimatized in running fresh-water at $18^{\circ} \mathrm{C}$. One-third of the animals were killed $2-4 \mathrm{~h}$ after their last feed; one-third after being kept fasting for 7 days; the remaining third after 2 weeks of starvation. The alimentary canal was isolated aseptically and slit in the anterior, middle and posterior one-third regions. From the intestinal contents several slides were prepared and evaluated.
In the actively feeding fish several bacteria were observed, distributed throughout the intestines; while in the fasting fish the gut appeared completely germ-free or showed rare, isolated forms, chiefly in the anterior onethird region.

In newts a rich and multiform microbial flora was observed, much more abundant in the hind-gut; there seemed to bo little if any difference in the quantity and quality of bacteria between actively feeding animals and fasting ones.

In the frog, either recently fed or starved, the intestinal flor: was constantly present and very copious. In the posterior tract of the gut it closely resembled the colonic flora of mammals.

Two other groups of goldfish and frog $(5$ specimens for each group) were fasted for 2 weeks. Then the stools of the last $24 \mathrm{~h}$ were collected and homogenized and the bacteria counted by numbering the colonies grown in agar plates inoculated with serial dilutions. The average number of bacteria found in the $24 \mathrm{~h}$ faeces of each goldfish was $2 \cdot 10^{\mathrm{R}}$; the corresponding number for each frog was $3 \cdot 10^{20}$ : that is, the microbial population present in the $24 \mathrm{~h}$ facces of a fasting frog is of the order of $1.5 \cdot 10^{12}$ times more than in the goldfish.

It seems, therefore, that terrestrial vertebrates, from amphibia to man, have evolved in intimate association with a complex indigenous flora of the intestine. On the contrary, in the intestine of fish, a true microbial flora appears to be absent or restricted to a scanty and labile form.

The explanation of such differences will be examined in a later paper.

Riassunto. E stato osservato che la flora microbica indigena intestinale, praticamente assente nei Pesci, si trova associata stabilmente nei Tetrapodi, a partire dagli Anfibi Urodeli e Anuri.

P. Boni and P. BattaglinI

Istituto di Biologia Genevale e Genetica dell'Università di Napoli (Italy), April 75, 1964.

1 T. W. M. Cameron, Endeavour 11, 193 (1952).

2 S. E. Mergenifacen, J. Bact. $71,739(1056)$

3 L. Margoits, J. Fish. Res. Bd. Can. 10, 62 (1953).

4 L. F. Potter and G. E. BAker, Canad. J. Microbiol. 7, 595 (1961)

5 A. Gufílin, Ann. Inst. Pasteur 103, 122 (1962).

a C. Hugatins and H. V. RAś, J. Bact. 85,489 (1963),

7 J. Liston, J. gen, Microbiol. 10, 205 (1957).

\section{Three Antifungal Polypeptides from Bacillus subtilis}

Among the antifungal polypeptides synthesized by different strains of Bacillus subtilis, the bacillomycins have been grouped together due to their great similarity in many respects: molecular weight, amino acid composition, pK, solubility, biological action, etc. ${ }^{1}$.

In this communication we describe three antifungal polypeptides obtained with a strain of $B$. subtilis derived from the original producer of bacillomycin $\mathrm{A}^{2}$. These compounds have several properties in common with the members of the bacillomycin family.
B. subtilis DINR 49-4 was grown in Povitsky flasks on potato broth admixed with $2 \%$ of glucose and $0.4 \%$ of asparagine. After 15 days' incubation at $25^{\circ} \mathrm{C}$ the culture was sterilized, brought to $\mathrm{pH} 3$ with concentrated hydrochloric acid and left overnight at $4^{\circ} \mathrm{C}$. The turbid liquid was stirred with Hyflo-Supercel (Johns Manville) and centrifuged. The solids obtained were extracted with hot

1 N. Suaron, A. Pinsky, R. Turner-Graff, J. Babad, and A. P. Cercós, Nature 174, 1190 (1954).

A A. P. Cercós, Rev. Invest, agríc. 4, 325 (1950). - A. P. Cercós and A. Castronovo, An. Soc. cient. argent. 152, 68 (1951) 